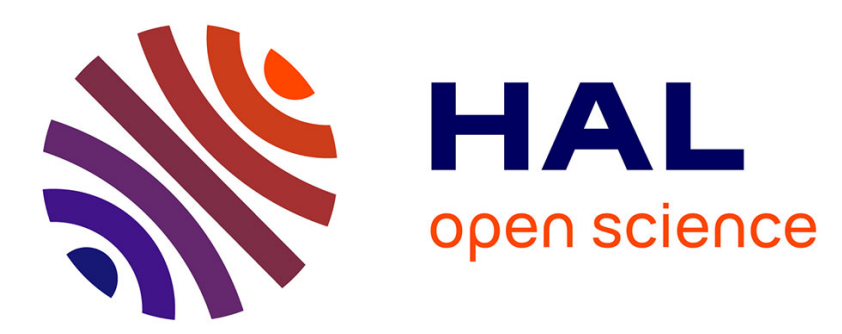

\title{
Quality management and contractual incompleteness: grape procurement for high-end wines in Argentina
}

\author{
J.M. Codron, E. Montaigne, S. Rousset
}

\section{To cite this version:}

J.M. Codron, E. Montaigne, S. Rousset. Quality management and contractual incompleteness: grape procurement for high-end wines in Argentina. 130th EAAE Seminar - Did agricultural economics disappoint? Empirical applications on Governance of Food and Fibre Value Chain, Aug 2012, Uppsala, Sweden. 39 p. hal-00762198

\section{HAL Id: hal-00762198 \\ https://hal.science/hal-00762198}

Submitted on 6 Dec 2012

HAL is a multi-disciplinary open access archive for the deposit and dissemination of scientific research documents, whether they are published or not. The documents may come from teaching and research institutions in France or abroad, or from public or private research centers.
L'archive ouverte pluridisciplinaire HAL, est destinée au dépôt et à la diffusion de documents scientifiques de niveau recherche, publiés ou non, émanant des établissements d'enseignement et de recherche français ou étrangers, des laboratoires publics ou privés. 


\section{0th EAAE Seminar}

\section{Did agricultural economics disappoint?}

Empirical Applications on Governance of Food and Fibre Value Chain

August 31 - September 1, 2012

Department of Economics, SLU, Sweden

Quality management and contractual incompleteness: grape procurement for high-end wines in Argentina

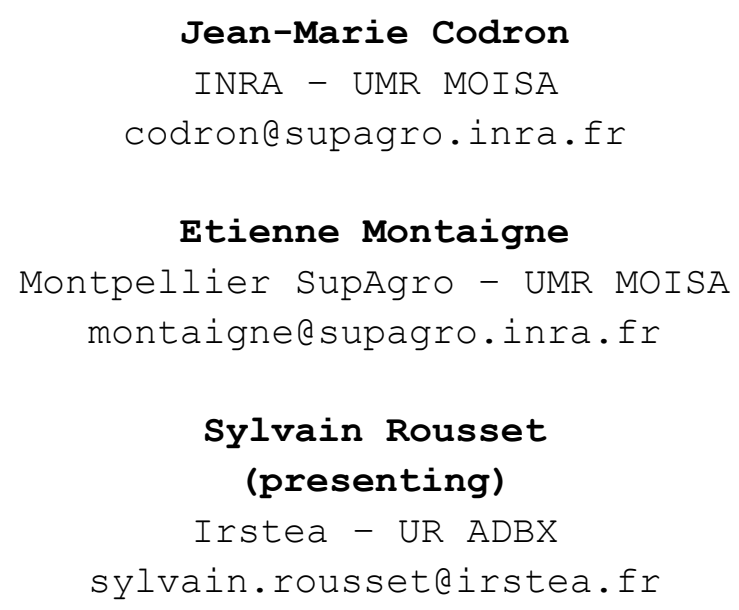

http://www.slu.se/en/faculties/nl/about-the-faculty/departments/department-ofeconomics/research/130th-eaae-seminar/ 


\title{
Quality management and contractual incompleteness: grape procurement for high-end wines in Argentina
}

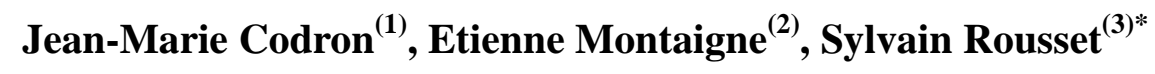 \\ ${ }^{(1)}$ INRA, UMR MOISA, 2 Place Pierre Viala, F-34060 Montpellier cedex 1, France \\ ${ }^{(2)}$ Montpellier SupAgro, UMR MOISA, 2 Place Pierre Viala, F-34060 Montpellier cedex \\ 1, France \\ ${ }^{(3)}$ Irstea, UR ADBX, 50 Avenue de Verdun, F-33612 Cestas cedex, France \\ *Corresponding author (sylvain.rousset@irstea.fr)
}

Paper prepared for presentation at the $130^{\text {th }}$ EAAE Seminar

Did agricultural economics disappoint? Empirical applications on Governance of Food and Fibre Value Chain

\author{
August 31 to September 1, 2012 \\ SLU, Uppsala, Sweden
}

Copyright 2012 by [J-M Codron, E. Montaigne, S. Rousset]. All rights reserved. Readers may make verbatim copies of this document for non-commercial purposes by any means, provided that this copyright notice appears on all such copies. 


\begin{abstract}
Sourcing grapes from independent growers for use in top quality wines sold on the international market is a major organisational challenge for corporate wineries. Our paper adds to the small existing literature addressing these coordination issues in the New World wine sector, by going deeper into the specifics of the contracts, as well as the "transaction cost economising" argument. Based on a case-study carried out in the Argentine province of Mendoza, this article presents an in-depth analysis of the technical process, in order to identify the contractual hazards posed by asset specificity, measurement costs, and non-contractible actions. Drawing on contract completion and dual sourcing literature, it analyses the contractual and non contractual mechanisms (price incentives, grower monitoring, allocation of decision rights to the winery, role of backward integration into production) used to govern such grape transactions. Through our analysis, we were able to arrive at four main conclusions. Firstly, most agreements are still verbal, with the exception of occasional written contracts, limited to a few legal provisions. It became clear to us that this approach to forging agreements is not always adequate in managing the inherently complex interactions between grape varieties, soil, farming practices and wine-making processes in high-end wine production. Secondly, extensive decision rights are allocated to wineries, to deal with incompleteness. These are key decisions to be taken during the cropping and harvesting process. Thirdly, pricing is generally kept flexible, with grape prices negotiated ex-post. This means that trade imbalances tend to be resolved in the long term. Winegrowers also benefit from financial rewards to compensate for allocations. Finally, any potential opportunistic behaviour by wineries with regards to asset specificity (in particular yield limitation) and allocation of rights is kept at bay by mechanisms such as winery reputations and credit third-party guaranty. This type of behaviour by growers is similarly deterred through monitoring and vineyard ownership on the part of the wineries.
\end{abstract}

\title{
Key-words
}

Incomplete contract, plural governance, quality, transaction costs, wine industry

JEL: D23, L66, Q13 


\section{INTRODUCTION}

Much like other food chains, but unlike European viticulture, New World wine chains are characterised by large-scale, brand-oriented processing companies alongside small-sized independent grape growers. Wineries continuously adapt the wine-making process and scope of grape varieties to better meet consumer demand, as well as transferring innovations further up in the grape production process. While the central position of the winery in the procurement chain makes for fairly efficient marketing, it also raises problems of coordination, in particular when securing volumes from independent growers, measuring and controlling the quality of the fruit and avoiding conflicts in sharing the rent with their suppliers.

In most supply chains, firms sourcing products from independent suppliers are faced with coordination problems. While some of these can be resolved through quality incentive contracts, others need the implementation of non-standard contracts and "hybrid" organisations such as supply chain systems and inter-organisational networks (Ménard, 2004, 2012). These governance structures provide incentives, and also play an important role in ex-post coordination, because legal contracts are incomplete and need completion to foster adaptation, and because cooperation between separate-ownership firms is faced with contractual hazards and often results in disputes with high risk of conflict. Governance structures thus serve three main objectives: allocating income rights, allocating decision rights, and solving conflicts (Hendrikse, 2003).

In the wine industry, various forms of contracting govern the relationships between grape growers and processors. Drawing on specific literature addressing the coordination issues in the New World wine sector (Goodhue et al., 2003; Fraser, 2005), we may infer that the more complex the quality of the wine, the more incomplete the form of contracting. However, most studies do not enter into the specifics of the contract that build upon a cautious description of the technical process, and overlook the complementarities that may exist between the mechanisms governing each of the transactions handled within a winery. Our paper aims to fill these two gaps. It is based on a detailed description of a set of large wineries in Argentina that aim to market a wide range of wine categories, 
including high-end brands. Theoretically, it draws on transaction cost economics (TCE) by focusing on the main transactional factors that influence the choice of a governance structure, in particular "ease of measurement", uncertainty and asset specificity (Barzel, 2005; Masten, 2000; Tadelis, 2002; Williamson, 1985). It also goes deeper into the efficiency argument, drawing on contract completion (Arrunada et al., 2001, 2005) and plural procurement literature (Dutta et al., 1995, Heide, 2003).

Our paper differs from the previous studies on grape contracts, in the following ways:

i) Case-study approach to apply the theoretical concepts more efficiently in practice.

ii) Consideration of the details of the institutional arrangements governing procurement and their evolution in the medium term.

iii) Instead of considering one transaction per firm, our study discriminates between the different institutional arrangements that govern transactions within a single winery, and looks for complementarities between them, especially those that may exist for top quality grapes between vertical integration and incomplete contracts.

To that purpose, in-depth interviews were conducted during winter 2010, with the senior staff of major Argentinean wineries and a sample of their grape suppliers in Mendoza, a province of western central Argentina accounting for $80 \%$ of the country wine production and exports.

The paper will be organised as follows. Section 2 analyses the coordination issues in the production of high-end wines by drawing on literature from the field of organisational economics. Special attention is paid to asset specificity, measurement problems, task programmability uncertainty, the allocation of decision rights, contract adaptation and enforcement, and plural governance. Section 3 provides main facts and figures about recent changes in the Argentinean wine industry. Section 4 reports the case-study on grape supply management in Mendoza, with a focus on the management of incomplete contracts. Section 5 concludes. 


\section{ORGANISATIONAL ISSUES IN THE PRODUCTION OF HIGH-END WINES}

Empirical research into grape contracts stresses that the difficulty in measuring grape quality leads to increased non-price coordination and direct control by customers (Fraser, 2005; Goodhue et al., 2003). Defining a sensorial style - particularly for high-end segments - is a critical step for wine producers. High-end wines are characterised by a drastic limitation of grape yield and a high interaction between multiple technical variables, such as area of production (district, vineyard plot), grape varieties, farming practices and wine-making processes. Yield may be reduced by one half or more due to extensive pruning. Yield reduction usually takes place at the request of wineries, and is designed to improve the quality of the finished product. This activity is a specific asset for their grape suppliers, it creates quasi-rent, as well as the potential for the hold-up of growers by the wine company.

The high interaction or strong complementarity between vineyard and winery has implications for the organisation of grape sourcing. Contrary to the middle-tier segment of "varietal" wines, where wine quality may be approximated by objective criteria such as ripeness or colour indexes measured on the grape, quality in the high-end is more complex, encompassing characteristics such as aroma concentration, which are not easy to produce and measure. Accordingly, it becomes essential for a wine company to manage the vineyard decisions which have a significant impact on the final product. This may be done through a transfer of decision rights from the grape grower to the firm. Transaction costs are therefore mainly derived from the need to protect specific assets from partner opportunism, the difficulty of measuring product quality, and the possible manipulation of information when allocating decision rights to the buyer for noncontractible actions.

After reviewing existing research on wine-grape procurement, we will give insights into the three main sources of transaction costs affecting high-end wine (asset specificity, ease of measurement, and task programmability uncertainty) and the two governance issues (contract design and plural governance) that help to reduce these transaction costs. 


\section{Previous work on wine-grape procurement}

Empirical literature on grape supply analyses the characteristics of contracts obtained through closed questionnaire surveys of growers, focusing on quality incentives (bonus, penalty), contractual requirements related to inputs, and farming practices. According to these studies, there is a trade-off between output measurement and input control. Goodhue et al. (2003) report the results of a postal investigation of 1,277 Californian grape producers. The study shows that price incentives for easily-measurable quality characteristics at delivery (especially fruit defects and material other than grapes) are less frequent in regions with higher priced grapes. In those regions, specific cultural practices are more often required or suggested by wineries. The survey of 527 Australian growers by Fraser (2005) shows similar results: in low-quality grape-growing regions, farmers are motivated by price incentives, based in particular on grape sugar content (potential alcohol yield after fermentation) whereas contracts in higher quality regions are associated with more frequent vineyard visits by winery staff and more explicit winery involvement and direction in vineyard management. A limitation of these two studies is that they do not go deeply into the allocation of decision rights to wineries. For example, in the econometric specification of Goodhue et al. (2003), "suggested" and "required" practices are grouped together. Another limitation is that they focus on contracts only, whereas dual sourcing is a key feature in the Californian and Australian wine industry, where wineries' own vineyards account for respectively $15 \%$ and $21 \%$ of supply (CDFA/USDA, 2012; Gordon, 2006).

Our contribution aims to provide an additional perspective on wine grape chain organisation. As was the case with a recent study on the Spanish Rioja wine industry (Fernández-Olmos et al., 2009), we are interested in the coherence (or alignment) between the characteristics of transactions and the governance of grape procurement.

Based on a survey of 187 wineries, Fernández-Olmos et al. (2009) showed that Rioja wineries producing high-quality wines are more likely to integrate vertically than those producing lower priced products. Consistent with TCE, growers' physical and dedicated assets increase the use of hierarchical governance, whereas the effect of physical asset specificity at a winery level is not statistically significant in the model. According to the authors, the results support the idea that integration is an efficient means of mitigating 
potential conflicts under incomplete contracting in the wine industry. One of our previous studies also puts forward the role of quality and asset specificity in wineries' choices. Drawing on an original survey of 145 French and New World wine brands, we show that vertical integration in grape production increases with site, human and physical asset specificity e.g. clones, trellising systems, farming practices, vineyard management, and contextual knowledge (Rousset, 2006).

\section{Asset specificity}

According to Williamson (1985), asset specificity is the main source of contractual hazards: specific assets are land, material, technical, immaterial, and human assets that give a process higher productivity or quality, but have little or no value elsewhere. As asset specificity creates quasi-rent and dependence, contractual relationships are subject to the hold-up problem, particularly if an opportunistic contracting party acts - or threatens to act - in breach of the initial contract (Alchian and Woodward, 1987; Klein et al., 1978; Williamson, 1985). Firms are prompted by competition to align governance structures with the attributes of the transaction, especially asset specificity (Williamson, 1985, 1991, 2005). This founding proposition of TCE has been validated by numerous empirical studies (Klein, 2005; Macher and Richman, 2008), even if some reviewers are more sceptical (David and Han, 2004). Provided that potential hazards are not high enough to justify full vertical integration, drafting a long-term supply contract with formal agreement on price, volume and certain clauses relating to resolving disputes, could mitigate the problem. Nevertheless, the principal limitation of such long-term supply contracts is their inflexibility in the face of changing market circumstances (Masten and Crocker, 1985; Klein, 1996). From a more general point of view, bounded rationality prevents the parties from specifying all contingent clauses.

Asset specificity has important implications for the organisation of wine-grape transactions. Six types of asset specificity have been identified in the literature on grape supply (Ayouz et al. 2002; Fraser, 2005; Fernández-Olmos et al., 2009; Traversac et al., 2011). 
(a) Temporal specificity is due to the perishable nature of berries and the need to use the winery at full capacity during harvest. This asset specificity affects all the categories of wine and explains why a minimum of coordination is required for harvesting, transporting and receiving grapes.

(b) Site specificity, which refers to the deployment of assets requiring geographic proximity between contracting parties. For instance, it can be generated when a wine company sets up in a new area with few grape producers or even farms. The development of the Marlborough wine region in New-Zealand in the 1970s is an example of this (Lewis et al., 2001).

(c) Physical specificity, which is induced by physical asset characteristics particularly suited to the contractual relationship. Examples of such physical specificity are numerous in the industry: investments in drip irrigation to comply with water stress management required by a wine company, the planting of new grape varieties, the establishment of a specific trellising system (for example, two-divided canopy trellis system).

(d) Human assets such as professional skills and capabilities are often considered to be readily re-deployable in agriculture and viticulture (Masten, 2000; Traversac et al., 2011).

(e) Brand-name capital such as private brands, trademarks and geographical indications, is often seen as important in the wine business. In the EU market, consumers infer a higher quality from products with Protected Designation of Origin (PDO). As a result, well-established PDOs represent valuable assets for farmers and have to be protected (Raynaud et al., 2005; Traversac et al., 2011).

(f) Dedicated assets, which are implemented to satisfy the other contracting party: these assets cause overproduction or underproduction in the event of sudden contract breakdown.

Yield limitation imposed by the buyer with the aim of increasing quality may be considered as a dedicated asset. It is undoubtedly one of the most specific assets invested by growers supplying high quality grapes. Surprisingly, we are not aware of any paper focusing on the role of yield limitation as a dedicated asset. 


\section{Ease of measurement}

Product quality evaluation plays a crucial role in the organisation of grape procurement. Since it is often costly to measure all desirable characteristics (Barzel, 1982, 2005; Eggertsson, 1990), buyers and managers have to rely on a limited number of proxies (Allen, 1993).

To understand what is at stake in the quality of wine-grape transactions, one must go back to the technical descriptors used in viticulture and oenology research. Marketing or branding wine on the basis of a specific sensorial "style" or set of sensorial attributes has implications for both the winemaking and grape growing processes. Defining wine style is therefore a critical step. Modern oenology identifies two main winemaking strategies.

Wine brands can be characterised either by standard quality easily identified by consumers, or by attributes that give some degree of complexity to the product (Bisson, 2001a, 2001b).

A basic strategy is to only target the absence of defects: wines are developed to comply with national and intergovernmental regulatory standards, i.e. Codex alimentarius and best oenological practices set up by the International Organisation of Vine and Wine (Hannin et al., 2006). Standard quality also includes wines that demonstrate a common set of characteristics, such as geographical origins or grape variety. For example, the "varietal standard" strategy is to produce a wine that expresses the characteristics of a certain grape variety, in reference to a global quality benchmark, with standardised sensorial characteristics easily identified by consumers (Martin, 2003). Such varietal wines are obtained through the blending of grapes from different areas, vinified over a short period of 2 to 4 months in stainless steel tanks, and sold in the highly competitive premium price band - i.e. between 5 and USD 10.

Growers producing grapes for premium wines are not required to comply with detailed vineyard specifications, but their grapes are evaluated using a quality grid established by the winery that highlights essential information for pricing (defects, acidity, soluble solids, etc.). Buyers motivate growers with ex-ante incentives: contracted grapes are paid with reference to the market (for example, indicative prices quoted by administrative district and variety), with bonus and penalty payments for quality achieved (or not) and evaluated through the grid. Providing high-powered incentives (Williamson, 1985), these 
types of contract use measurement (Hueth et al., 1999) as the main coordination instrument to foster growers' effort. However, incentive schemes such as this are efficient only if effort and quality are strongly correlated (Mahoney, 1992; Hueth and Melkonyan, 2004). In the low price wine industry, Brix level, total acid and sugar/acid balance at delivery are consistent indicators of quality, and there is a good correlation between those characteristics and vine practices (yield target, choice of harvest date, etc.). It can therefore be said that results-orientated contractual incentives are effective in motivating growers.

In the second winemaking strategy, the brand offers specific flavours that noticeably differ from mass-market beverages. The process is based on a specific interaction between grape varieties and soil, and the control of both the grape production and winemaking processes. These high-end wines are therefore characterised by the interaction of multiple technical variables, such as the production area (region, district, vineyard, parcel), the selection of grape varieties (wines are produced using at least $85 \%$ of the same grape variety), the farming practices and the winemaking process (requiring specific tanks and oak barrels for ageing periods of one year or more).

Contrary to the basic and premium price segments, quality in the high-end segments cannot be achieved through objective measurement alone. A good example is aroma concentration, which is difficult to measure in grapes. Even if indicators of aroma concentration such as colour have been introduced as a payment tool for some red varieties like Shiraz in Australia (Kennedy, 2002), there is still doubt among experts about a possible replication of simple or even multi-criteria indicators for high-end wines, because of complex and non-linear relations between analytical measurements carried out on grapes, and secondary wine flavours.

Absent objective aroma indicators, two solutions may be used for evaluating high end quality and use it for grower payment: bottle pricing and wine tasting. Bottle pricing or payment contingent on the price of the final product is currently used by a small minority of Californian and Australian wineries (Ligon, 2001; Fraser, 2005). However, this pricing scheme, which may be considered as residual claimancy of the winery, exposes the grower to moral hazard. Vineyard and winemaking practices are closely connected, and have an impact on the sensorial quality of the product, which cannot be evaluated 
separately. High-end wine segments are thus faced with team production or nonseparability issues (Mahoney, 1992; Sykuta, 2005). Ideally, wine tasting could be a solution, especially for ultra-premium brands, where separate batch fermentation and wine ageing facilitate traceability. While such a measurement device may be useful in vertically integrated chains, it proves unsatisfactory as soon as there is a need to contract with independent growers. One reason is that wine tasting is a subjective assessment, and therefore not legally enforceable. In addition to this, processes carried out in the winery may downgrade grape quality from that present at delivery. Another shortcoming of this approach is the difficulty in implementing effective traceability, thus making it all but impossible to provide appropriate incentives to growers. Given such high measurement costs on the final product, the two parties may be better off negotiating winery control over some key actions of the grape production process likely to have a significant impact on the final product.

\section{Non-contractible actions}

Long-term contracts with buyer's requirements help to overcome contractual hazards associated with difficult-to-measure quality (Jang and Sykuta, 2009). According to agency theory, when there is little uncertainty on task programmability and a strong correlation between agents' effort and output (Allen and Lueck, 2003; Sykuta, 2005), the buyer could theoretically design a complete contract, including production practice rules, as in the hog case reported by Jang and Sykuta (2009). However, uncertainty (Williamson, 1985), complexity (Masten, 1984; Tadelis, 2002) or low task programmability (Mahoney and McNally, 2004) may forego the writing of a complete contract with detailed terms covering all possible events.

In grape production, private rules that are easy to monitor, and may be included as formal clauses in a contract, are rules over the use of inputs (rootstock, variety) and rules over some farming practices (planting density, trellising, irrigation system). However, due to climatic variation and other unforeseen events, not all farming practices that play a decisive role in high-end wine quality can be planned in advance and specified in a written contract. A good example of a vineyard practice that has to be adjusted at short 
notice is cluster thinning in summertime, which accelerates ripening and improves the quality of the grapes, while reducing yield.

In such a context, the rights that cannot be specified in a contract may be allocated to one of the partners in order to reduce transaction costs (Barzel, 2005; Arrunada, 2005). However, the allocation of rights leads to the possibility of opportunistic behaviour on the part of the principal. As a result, the agent accepts to transfer rights if he is granted monetary advantages, and can benefit from efficient private enforcement mechanisms, such social norms, relational trust, or reputation. The rights over non contractible actions may be called residual rights or economic rights as opposed to the specific or legal rights that may be included as a formal clause in a contract (Demsetz, 1998; Barzel, 2002). Hence, a complete contract only includes specific rights, whereas an incomplete contract provides large scope for residual rights. Hu and Hendrikse (2009) conducted a multiple case-study of Chinese fruit and vegetable companies, where buyers are allocated decision rights over the use of inputs (specified seeds, fertiliser or pesticide), cultural and postharvest practices, and monitoring rights such as direct inspection of farmers. The authors suggest that the number of decision rights increases with product quality, consistent with the hypothesis that an allocation of decision rights also helps mitigate agents' opportunistic behaviour. Moreover, they show that the granting of extensive decision rights to the buyer exposes the growers to a large risk of expropriation, with the main safeguard against the abuse of power being the buyer's reputation.

The transfer of authority over vineyard practices to the winery reduces the costs of adaptation and allows the implementation of best practices for quality management ${ }^{1}$. This transfer is voluntary, and negotiated for the duration of the contract. During the growing season, winery staff regularly visit grape producers under contract. These technicians have the authority to monitor growers and oversee the day-to-day use of farm inputs and/or good cultural practices, contributing to the improvement of vineyard management and the production of grapes tailored to the winery's needs.

\footnotetext{
${ }^{1}$ To our knowledge, there is no empirical research in the wine sector dealing with the allocation of decision rights to the buyer.
} 


\section{Governance structures}

Transactions of agricultural products are embedded in governance structures, which range from market governance to hybrids organisations, where firms pool resources without being integrated into a single command (see the synthesis of Ménard, 2012). According to Hendrikse (2003), governance structures serve three main objectives: allocating income rights, allocating decision rights (or authority) and solving conflicts. In addition to providing incentives, they play a decision role in adaptation, because legal contracts are incomplete.

(i) Allocating income rights: This consists of defining the distribution of costs and revenues between partners, while limiting adverse selection and moral hazard, in particular thanks to incentive-compatible pricing (Hendrikse, 2003). For instance, in agricultural contracts, payment can be non-differentiated (commodity pricing), flat-rate (par acre payment) or cost-plus; it may conversely provide stronger incentives, with residual claimancy or quality contingent payment.

(ii) Allocating decision rights: To cope with unforeseen events, parties should either promise to act in "good faith" or allocate residual rights to one party (Hviid, 2000). In a seminal study, Maccaulay (1963) argues that businessmen often do not plan every future event in legally binding contracts, but rather fill the gap with informal relationships, bringing into play trust, reputation, the repetition of transactions, and norms of reciprocity, adjusting exchanges by mutual agreement, and settling disputes by negotiation. In relational governance, contracting is not merely about enforcing statecontingent claims, but also putting in place rules to govern the relationship over the long term (Eccles, 1981; Goldberg, 1976). Poppo and Zenger (2002) operationalise relational governance with four underlying dimensions: open communication and sharing of information, trust, dependence and cooperation.

Ménard (2012) emphasises the role of authority in exercising control over and instilling discipline in the members of hybrid organisations such as cooperatives, franchises, supplier parks, or strategic alliances. Authority is only exerted on a limited subset of rights, and because it is based on mutual consent, authority is different from the hierarchical relationship within a firm, and maintains symmetry between partners. However, authority can also be imbalanced: in subcontracting, one firm (the contractor) 
often has extended decision rights to adapt the contract (Ménard, 2012).

(iii) Solving conflicts and enforcing promises: The cooperation between separateownership firms naturally carries hazards and a potential for disputes, especially in complex and developing environments. To enforce their agreements, it is rational for parties to take advantage of more than one enforcer, each enforcing the components of the agreement for which it enjoys a comparative advantage. The contractual part of an agreement is enforced by the State, and deals with objectively measurable and verifiable commitments; the non-legal part, enforced by reputation (calculative trust) or by norms of obligation and cooperation, deals with attributes that are costly to measure at the time a transaction takes place (Barzel, 2005).

Non-legal mechanisms such as reputation or private arbitration can help to overcome critical problems of non-verifiability for certain characteristics of agricultural transactions. Indeed, new investigations within organisational economics have proved the very important role of reputation as an alternative mechanism to vertical integration in the presence of contractual non-fulfilment and asset specificity (Baker et al., 2002). According to Maccaulay (1963), even when there is room for opportunistic behaviour, the promises to act in "good faith" may be enforced by social norms, reputation and the exchange of hostages. The reputation mechanism works well in small groups, where low information costs and cultural homogeneity encourage retaliation and black-listing, with a real risk of losing future business. Indeed, the enforcement of commercial agreements in merchant communities has been extensively studied (for a survey see Richman 2004). In larger professional groups, deterring misbehaviour while limiting transaction costs often requires formal private institutions to act as third-party enforcers, gathering evidence and punishing those who act dishonestly (Greif et al., 1994).

There is no consensus in literature on whether public (legal) and private enforcement devices are substitutable or complementary. Substitutability is supported by those who show that well-specified contracts undermine the capacity to develop informal agreements and inter-firm trust (Maccaulay, 1963; Palay, 1985), or that firms sometimes rely on private ordering simply because there is no effective law or no confidence in the judicial system to settle disputes (McMillan and Woodruff, 1999). Conversely, complementarity is argued by scholars who assert that a joint use of formal and informal 
arrangements allows better enforcement of commitments (Lazzarini et al., 2004) or that formal contracts embedded in relational governance narrow the risks of opportunistic behaviour and increase punishments (Poppo and Zenger, 2002). Likewise, Klein (1996)

gives insights into the "self-enforcing range" of contracts by demonstrating that the private enforcement capital of firms (i.e. their capacity to impose sanctions by threatening to terminate the relation or to damage the other firm's reputation) defines the extent to which parties honour their commitments, without cheating when external conditions change (for an application in agri-food, see Mazé and Ménard, 2010).

In the quality wine industry, incomplete grape contracts combine explicit court-enforced terms (varietal, volume, exclusive dealing, and legalistic "force majeure" clauses) and self-enforcing relational clauses: required farming practices, the right of the winery to choose harvest timing, and often pricing. In developed institutional environments like the Champagne wine industry, parties may complement these two devices with third-party enforcement embedded in a regulatory framework (Lanotte and Traversac, 2011).

\section{Plural governance}

In the high-end segment, wine producers will often mix grapes obtained from their own vines with those bought in from third-party growers.

Literature on plural (or dual) forms of distribution and procurement has developed in activities such as industrial distribution (Dutta et al, 1995), restaurant chains (Bradach, 1997), haulage companies (He and Nickerson, 2006), the purchasing of component by equipment manufacturers (Heide, 2003) or the procurement of raw material by metal forming companies (Parmigiani, 2007). Four explanations are consistently found in this literature, which appears somehow to contradict the "discrete alignment" hypothesis of TCE (Williamson, 1991).

i) Shifting risk: The traditional explanation is that facing demand uncertainty, integrated firms are willing to ensure full internal capacity and stable production, and transfer the fluctuations in volume to subcontractors (Adelman, 1949, quoted by Parmigiani, 2007).

ii) Solving information asymmetries: According to agency theory, internal production helps monitor distributors or suppliers. In a context of performance ambiguity, the integration of sales force (house account) allows for better monitoring of the actions of 
representatives, and provides benchmarking (Dutta et al., 1995). According to Heide (2003), in-house expertise reduces adverse selection by improving the ability to assess suppliers' characteristics, and mitigates moral hazard in contracting by designing more efficient systems of behaviour control.

iii) Ratcheting: The two governance structures have different capabilities and incentives properties, and this is a source of synergy and organisational efficiency. In a study of fastfood chains, Bradach (1997) analyses the ratcheting effect, in which the performance of one arrangement is used to set the standard of the other, in a continuous dynamic process. He also shows how the plural form builds on the mutual learning process between the company and its franchisees, the former providing formal expertise, procedures and the management of information systems, and the latter a knowledge of local market conditions and ideas for new strategies.

iii) Reducing transaction costs: An empirical study on industrial purchasing (Heide, 2003) shows that the interaction between asset specificity and external uncertainty increases the likelihood of a plural form rather than unique market governance. One explanation is that an in-house operation enhances the ability of manufacturers to adapt in the supplier relationship, when it is difficult to write complete contracts.

Existing literature gives few predictions about real-world governance in the wine industry, because the benefits of the plural form (better monitoring and ratcheting of the supplier) do not require a high degree of vertical integration. For many large-scale wine producers, forty or fifty hectares is sufficient. Indeed, anecdotal evidence suggests that wine giants such as Ernest and Julio Gallo and Constellation Brands are still producing a few percent of there lower-priced grapes in-house. The TCE explanation (providing credible threat to enforce incomplete contracts) has a better discriminatory power, in a sense that high-quality production has to deal with high uncertainty and non-verifiability; however, it ultimately depends on the extent of asset specificity.

To summarise this section (Figure 1), wineries looking to produce high-end wines need to manage complex interactions between grape varieties, soil, farming practices, and winemaking and ageing processes. As a result of this, when procuring grapes from independent growers, wineries face high measurement costs and cannot rely only on proxies of product quality as is the case with wines in lower price categories. Input 
control and grower monitoring are therefore the two main coordination instruments. However, because of uncertainty and non contractible actions, contracts are left incomplete, with allocation of control rights to the technicians of the winery and room for adaptation during the growing season.

Figure 1. Organisational issues in wine-grape procurement: summary.

\begin{tabular}{|c|c|c|c|}
\hline \multicolumn{2}{|l|}{ Issues } & $\begin{array}{l}\text { Basic and premium } \\
\text { varietal wines }\end{array}$ & $\begin{array}{l}\text { Super/ultra premium } \\
\text { wines }\end{array}$ \\
\hline \multirow[t]{3}{*}{$\begin{array}{l}\text { Coordination } \\
\text { problems }\end{array}$} & Asset specificity & Low & $\begin{array}{l}\text { High (yield limitation } \\
\text { in particular) }\end{array}$ \\
\hline & $\begin{array}{l}\text { Difficulty in } \\
\text { measuring product } \\
\text { quality }\end{array}$ & Low & High \\
\hline & $\begin{array}{l}\text { Task programmability } \\
\text { uncertainty }\end{array}$ & Low & High \\
\hline \multirow[t]{4}{*}{$\begin{array}{l}\text { Coordination } \\
\text { instruments }\end{array}$} & Residual claimancy & & $\begin{array}{l}\text { Some evidence (bottle } \\
\text { pricing) }\end{array}$ \\
\hline & Measurement & $\begin{array}{l}\text { Use of proxies } \\
\text { (ripeness indicators) }\end{array}$ & \\
\hline & Input control & $\begin{array}{l}\text { Variety, sometimes } \\
\text { trellising system }\end{array}$ & $\begin{array}{l}\text { Variety, parcel, } \\
\text { trellising system, } \\
\text { pruning (buds/cluster } \\
\text { density), canopy } \\
\text { management }\end{array}$ \\
\hline & Monitoring & & Frequent visits \\
\hline \multirow[t]{3}{*}{$\begin{array}{l}\text { Governance } \\
\text { structures }\end{array}$} & Income rights & Market price & $\begin{array}{l}\text { Guaranteed price } \\
\text { (floor/window } \\
\text { formula, cost plus), or } \\
\text { negotiated price }\end{array}$ \\
\hline & Decision rights & $\begin{array}{l}\text { No allocation to the } \\
\text { winery }\end{array}$ & $\begin{array}{l}\text { Allocation for a wide } \\
\text { range of cultural } \\
\text { practices }\end{array}$ \\
\hline & Enforcement rights & Termination at will & $\begin{array}{l}\text { Monitoring } \\
\text { Reputation }\end{array}$ \\
\hline
\end{tabular}




\section{THE ARGENTINEAN WINE INDUSTRY}

\subsection{Recent changes in Argentina}

Argentina is a country of great interest for the study of coordination in the wine industry. In 2011, the country was ranked 9th in terms of vineyard area (217,750 hectares, 2.9 percent of the total worldwide area), 8 th for grape production, $5^{\text {th }}$ for wine production (15.5 Mhl, 5.8\%), and $9^{\text {th }}$ for wine export by volume (3.1 Mhl, $3.2 \%$ of worldwide production and a quarter of the national production). There are 24,780 vineyards in Argentina, with wines produced by 974 wineries, and exported by 477 different companies (Source: Instituto Nacional de Vitivinicultura, 2012).

Starting in the 1990s, many foreign companies recognised the potential of Argentine wine-growing regions, and invested heavily in the cultivation of high-end grape varieties in the country. This new investment, accompanied by the construction of modern bodegas (wineries), represented a significant change in the industry. Before long, local investors also began to inject money into their national wine market. This combination of new developments was supported by an economically stable Argentine economy in the 1990s. Between 1991 and 2001, there was high investment in the Argentine wine business, with 500 million USD of domestic investment, and one billion USD from overseas (Stein, 2008). A good example of the situation at that time is the Tupungato winelands project in the Uco valley, where 10,000 hectares of irrigated vineyards were installed. The economic policy implemented according to the "Mendoza-San-Juan Agreement "in 1995, contributed to a stabilisation of wine supply, and a gradual increase in prices. Despite the economic crisis of 2001, development remained unaffected, mainly due to devaluation of the peso and the resulting fall in labour costs. As a result, Argentina was able to continue producing good quality, value-for-money wines.

The cornerstone of this flourishing new wine business was a continuous striving to improve grape quality. This was achieved through a variety of methods, including modification of water management (introduction of drip irrigation, targeting a moderate water deficit), trellising systems (from the traditional pergola to modern canopy management), the use of successful varieties (Vinifera) grafted on Phylloxera resistant rootstocks, and the introduction of nets to protect vines from hailstone. Another part of 
this quality-driven development was the modernisation of wine-making equipment in bodegas throughout the 1990s and 2000s. Vineyard staff also benefited from enhanced training, with external oenologists and technicians being brought in to share their expertise. The upshot of all these developments was a greater focus on the export market, particularly for premium and top-of-the-range wines.

At the same time, marketing strategies were devised to target a new generation of wine consumers, namely those from countries not previously associated with high day-to-day wine consumption. These new wine drinkers, who appreciated unpretentious, easydrinking beverages, were a key factor in the success of Argentine wines. Alongside these new, easily accessible wines, Argentina also became known as a producer of fine wines, especially those made from the Malbec grape variety. As shown in figure 2, export figures sky-rocketed from the late 1990s onwards. The great majority of wines exported in 2011 (68\%) were made from international varietals such as Chardonnay, Cabernet Sauvignon, or Malbec (Source: INV, 2012).

Figure 2. Evolution of wines and concentrated must exports between 1990 and 2008.

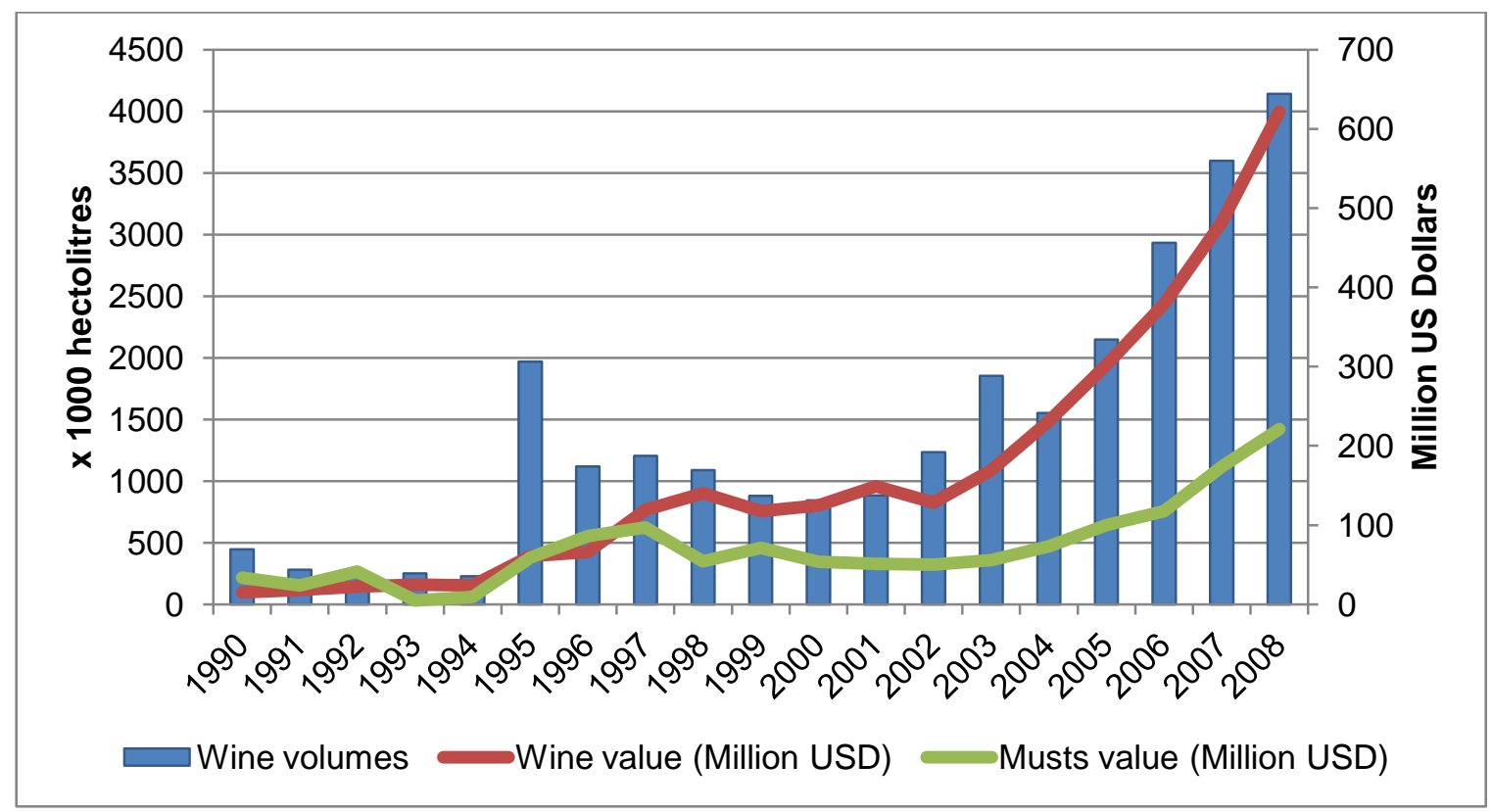

Source: INV, Statistical synthesis 1991-2008. 
Despite far-reaching changes in Argentine vineyards over the last two decades, the majority of the vinestock is fairly old, with a large amount of common local vines (criollas). These grapes are mainly used to supply the domestic market, which still accounts for three quarters of all consumption of Argentine wine. Wines marketed within Argentina are generally less expensive, and tend to be sold without any indication of the grape variety, as well as being of a lower quality (in 2011, 65\% of wines were sold without varietal labelling).

It is therefore possible to identify two key types of wine production: on one hand there is the basic wine production, aimed at the domestic market, and on the other hand there are the premium and high-end labels. The latter category is generally produced by the most modern bodegas, who have either recently opened, or have the necessary financial means to adapt their production methods. Basic wines are predominantly made by large companies or cooperative cellars, who buy in grapes from small private growers without the means to re-plant their vine stock. The key to the success of this market are low production costs, which can only be maintained by adopting a bulk-processing approach to winemaking (Van den Bosch and Vitale, 2010).

\subsection{The Mendoza wine supply chain}

The biggest Argentine wine-producing area is Mendoza, which produces over $67 \%$ of domestic wines, and is responsible for $80 \%$ of exports. In 2009, the region had 160,704 hectares under vine, 16,983 growers, and 682 wineries, out of a total of 952 for the whole country. In the same year, Mendoza produced 8.6 million hectolitres of wine and 2.5 million hectolitres of concentrated must. Mendoza vineyards are mainly located in the northern oasis, which was also one of Argentina's first ever wine-growing areas (Van den Bosch, 2008). Most of the bodegas are also located in this part of the region, along with a number of bottling companies, to cater for those wine estates without their own bottling facilities.

In the basic wine sub-sector, there are different highly-specialised stakeholders, which create a fragmented agri-food chain. On one hand, there is a network of cooperatives, the Federación of Cooperativas Vitivinícolas Argentinas (FECOVITA), with their affiliated growers, and on the other hand there are the independent growers, who sell their grapes 
to private bodegas. These companies in turn have their own set of characteristics. Some produce, bottle, and brand their own wine, whereas others do not have the facility to do so. These lesser-equipped producers, referred to as "trasladistas" (Van den Bosch and Vitale, 2010), export wine in bulk or sell it to factories for bottling.

Grape growers have access to a "terceros" system, or third-party wine production, whereby their grapes are provided to a bodega, who will make the wine under the grower's own name. With this arrangement, the grower can either choose to sell the wine themselves, or sell it directly bodega providing the vinification service. The latter represents the most common chain of events (Lumbroso, 2010).

The quality wine chain (over 5 USD per bottle) has a simpler vertical organisation. This subsector represents approximately 3,000 grape growers and 250 wineries, with or without their own vineyards. For the wineries, the first category to be distinguished is that of the large, forward-integrated estates who produce and bottle their wine in-house. These producers tend to fall into the middle price bracket (5-10 USD per bottle) and are very competitive with their pricing strategies. In Mendoza, there are six main companies of this type: Santa Ana, Cavas de Santa María, Michel Torino, Orfila, La Riojana, and Covisan. Most of their wine is sold to mass-market customers such as supermarkets and retail chains. The other types of bodega are those with integrated production, but without on-site bottling facilities. These estates externalise packaging or use mobile bottling services, with which they can bottle and package their wines on site, and prepare them for bulk export. Within this category, three types of companies can be identified:

i) Large companies, which have their own vineyards, and also source grapes from independent growers. They market wines in bottles or in bulk, under their own brand or that of a distributor, and also work with the domestic hotel and catering market.

ii) Former cooperatives and bodegas trasladistas who have shifted their focus towards higher-quality wines. They export their products in bulk or in bottles, mostly as supermarket own-brand wines.

iii) Bodegas dedicated to small-scale production (bodegas boutiques). These producers exclusively use grapes from their own vineyards. The development of producers such as these is closely connected to wine tourism, as their "rustic" image is appealing to visitors. Most of their wine is sold directly to consumers, or through the restaurant trade. 
The bodegas of Mendoza can secure grape sourcing in three different ways, either from their own vineyards, from independent growers, or as a terceros service provider. Figures on these three grape sourcing methods have varied over the years. In 2009, grapes obtained by bodegas from their own vineyards accounted for $36 \%$ of total production, with the remaining 64\% supplied by independent growers, 33\% of which was through the terceros system. However, statistics were quite different for premium grapes, $62 \%$ of which are grown "in house". The amount vinified under terceros agreements is negligible (Van den Bosch and Vitale, 2010).

To understand the quality improvement process, it is important to examine the design of grape supply contracts, particularly as it applies to the relationships between large companies and small-scale growers producing premium grapes.

\section{GRAPE SUPPLY MANAGEMENT IN ARGENTINA}

The case study is based on semi-structured interviews conducted in early 2010 with the senior management and field staff of seven Mendoza wineries, as well as some of their grape suppliers (Lumbroso, 2010). Follow up was carried out via email. In the interest of confidentiality, no winery is mentioned by name.

The main subject of our study was one of the main bodegas in Mendoza, which for the purposes of this report will be referred to as Bodega Campos (BC). As a subsidiary of a leading global beverage company, $\mathrm{BC}$ is a market leader in the sale of still and sparkling wines. Having operated in Argentina for over fifty years, the company decided to make a foray into the export sector, producing high-quality wines to sell around the world. For several years now, $\mathrm{BC}$ has been working with a famous French Bordeaux wine producer on an icon wine priced at 50 USD per bottle.

\subsection{Vineyard selection}

Every wine produced by $\mathrm{BC}$ requires different grapes. Classification of grapes by the bodega reflects their quality, but above all their target market. The choice of grapes and resulting characteristics are determined by the required wine style. For example, if the goal is to produce an easy-drinking wine, less concentrated grapes will be selected. 
Grapes are divided into grades. They are initially sorted into those destined for use in still wines, and those intended for sparkling wines. The latter are placed into a single category, known as grade E. The distinction between these grapes is made at the zone level, with the potential of every plot of land being known as well as the usual destination of its grapes. For still wines, there are five different categories of grapes, which correspond to the five ranges of wines produced by the bodega. Each category of wine has its own specific quality targets for grape quality, requiring a particular type of work for each class of vineyard. The lowest categories correspond to grapes which are relatively easy to obtain. Higher quality wines demand very particular types of grapes, which by definition are harder to come by, as their cultivation is much more technically demanding.

The bodega procures grapes both from its own vineyards and from independent growers. Every year, BC's commercial department adjusts its multiannual plan of sales and transmits it to the winemaking department. The plan is converted into volumes for each category of wine, and then into volumes for each category of grapes according to the rules of blending specific to each category of wine. Volumes of grapes for the next growing season are approved by the vineyard department, who predict the amount of grapes that will be obtained in-house, and the amount that will need to be purchased from outside growers.

Initially, $\mathrm{BC}$ classifies grape growers into quality groups, from $\mathrm{E}$ (lowest grade) to A (highest grade). This ranking is calculated using an evaluation report from company technicians. For newcomers, the report deals with "signal" variables. Grape suppliers are chosen based on grape varieties, the homogeneity of their vineyards, canopy system, and sanitary condition, which are prerequisite. Then the classification depends on a vineyard's specific potential (climatic zone, soil, vineyard management). Elements taken into account when assessing existing suppliers include loyalty and past performance.

The final classification of grapes is decided through negotiations with growers, and depends greatly on the kind of vineyards practices that a particular grower agrees to implement. The higher the category, the more demanding the vineyard practices (vine pruning, bunch thinning, canopy management, deficit irrigation, etc.). In practice, BC does not monitor all its producers the same way. More attention is paid to newcomers, growers changing category or growing grapes for the more demanding wines. Of course, 
technicians' knowledge of vineyard potential and grower or manager practices increases with time for regular suppliers.

In the low and middle price bands, growers receive monetary incentives based on easily measurable variables. BC obtains the vast majority of their supply of local grape varieties (criollas) through the spot market or other wineries. For premium (C and D) varieties, short-term verbal contracts tend to be agreed.

For high-end production (A and B grades), the winery favours a more centralised governance, with vertical integration and incomplete contracts embedded in long-term relationships. Decision and control rights over a set of vineyard practices are negotiated and voluntarily transferred to $\mathrm{BC}$ for the duration of the contract. During the growing season, winery staff have authority over the day-to-day use of grape farm inputs and strategic cultural practices. Contracts are however still mostly verbal with an assumed yearly renewal of these agreements. Even written contracts are kept very simple and incomplete; for those contracts, private enforcement is therefore a central issue.

\subsection{Lower-priced wines: quality incentive contracts}

BC manages grape quality for low and middle tier segments with contractual incentives, through the use of credible signals and contractual monetary incentives (price premium). Signal variables reduce information asymmetry, provide the bodega with a good opportunity to define the vineyard potential for quality, and help define groups of producers for each segment. The buyer relies predominantly on short-term oral contracts for premium varietal wines. Duration is not clarified, but the verbal commitment generally runs for one crop year. Moreover, no yield restriction is imposed on the grower. Companies benefit from competition among grape producers, and use the "market price" for payment. The market price is area and variety specific, and based on the previous year's grape prices, as reported by the regional Board of trade (Bolsa de Comercio de Mendoza). For instance, a generic Cabernet Sauvignon grape from the Maipù area will not require any particular specification. A price premium - which may increase the market price by up to $20 \%$ - is granted according to the score obtained from the grid-based evaluation at different stages of the production cycle (protocolo). The grid includes 
weighted values relating to vineyard quality, harvest quality, and sanitary state. It combines various criteria, each of which are given a score out of ten (Figure 3).

Vineyard monitoring serves to assess potential grape quality, and whether particular grapes belong in the category to which they have been assigned (it is important to estimate the sanitary quality of both grapes and vineyards, because even if a vineyard is contaminated by a fungal disease or parasite, the grower may have selected the healthiest clusters for harvest testing).

Figure 3. Example of a quality evaluation grid.

\begin{tabular}{|l|l|l|l|}
\hline Quality & Checkpoint & $\begin{array}{l}\text { Percentage } \\
\text { of overall } \\
\text { score }\end{array}$ & Measurements (1-10) \\
\hline Vineyard & $\begin{array}{l}\text { Vineyard - inspection } \\
\text { during growing season }\end{array}$ & $45 \%$ & $\begin{array}{l}\text { Vineyard homogeneity, } \\
\text { canopy balance, sanitary } \\
\text { state }\end{array}$ \\
\hline Harvest quality & $\begin{array}{l}\text { Checks at time of } \\
\text { delivery }\end{array}$ & $\begin{array}{l}\text { Quality of harvest box } \\
\text { stacking, mud residue } \\
\text { inside and outside boxes, } \\
\text { grape integrity, leaf } \\
\text { fragments }\end{array}$ \\
\hline Sanitary state & $\begin{array}{l}\text { Checks at time of } \\
\text { delivery }\end{array}$ & $\begin{array}{l}\text { Fungal damage (Powdery } \\
\text { mildew, downy mildew, } \\
\text { rot), hail }\end{array}$ \\
\hline
\end{tabular}

Source: interviews with BC.

$\mathrm{BC}$ has been using the same grape evaluation system for over twenty years. Scores obtained through this system are generally good, with $90 \%$ of producers achieving eight to ten out of ten. A secondary effect of this method of evaluation is that most grape growers have now changed their methods to ensure they obtain a satisfactory rating. The standards expected by BC of their growers are widely known, even among new contractors. Disputes are rare, because the rules are clearly understood by all parties. However, occasional disagreements do occur vineyards classification, where a grower considers their grapes to be worthy of a higher category than that assessed by BC's staff. 


\subsection{High-end brands: incomplete contracts}

For super and ultrapremium wines, grapes from different plots are crushed separately, and their must is vatted in different tanks. To procure fruit, $\mathrm{BC}$ relies on vertical integration and incomplete contracts embedded in long term relationships.

Suppliers must agree to frequent, unannounced visits from representatives of the company, and must also keep detailed records of their growing practices, particularly those involving the use of chemicals. In certain cases, the company may even supply or require the use of specific brands of pesticide. The frequency of these visits depends largely on the characteristics of the grapes. If the variety being grown is very technically demanding, there will be greater supervision. The skill and experience of different growers are also taken into account. Inspections tend to target new suppliers, or those who have performed poorly in the past.

Fruit evaluation on vineyard help determine an optimal date of harvest for each parcel and fixing a delivery date for growers. As the harvest time draws closer, more frequent visits are made to give $\mathrm{BC}$ an idea of the maturity of that year's grapes. Harvest and delivery dates are determined based on refractometry and berry tasting.

There are two types of formalisation to frame the relationship between the bodega and its external grape growers: written and verbal agreements. The latter is still the most common type of agreement, despite pressure on the technical director from the legal department to increase the use of written contracts. These formal contracts tend to be used only when dealing with producers of the highest quality grapes. At the time of publication, a mere nineteen written contracts had been signed.

Contracting begins with the bodega telling the grower the volume and type of grapes it wishes to buy. These details are generally agreed early on in the production cycle, at the latest before pruning, as yield limitation is a key operational factor. The exact price is not fixed in advance, but negotiated after harvesting ${ }^{2}$.

\footnotetext{
${ }^{2}$ While pricing is generally per ton and kept flexible, there is also a system of fixed pricing per hectare, used by several interviewed bodegas, including BC, in very strategic cases. It is a strong guaranty of quality for the winery as it neutralized grower's trade-off between yield and quality; at the same time, it provides insurance for the grower, shifting risk to the winery. For example, in case of problems of flower abortion (coulure), the bodega will receive fewer grapes, while paying the same price. However, in case of hail, the contract of BC includes a clause according to which the percentage of lost production is deducted from the price normally paid by hectare. For
} 
Written contracts are quite short (three pages) and allocate extended residual rights to the bodega (Figure 4). The key elements of the contract are duration of the contract, volume and variety of grapes, size of parcels, action to be taken in the event of an accident, or sale of the vineyard, enforceable non-compliance.

Figure 4. Written contract for high quality grapes.

\begin{tabular}{|c|c|}
\hline Specific rights & $\begin{array}{c}\text { Residual rights } \\
\text { (allocated to buyer) }\end{array}$ \\
\hline $\begin{array}{l}\text { Duration: five years. } \\
\text { Full delivery of grapes with expected } \\
\text { volumes estimated by multiplying surface } \\
\text { by expected yield. } \\
\text { Price: to be fixed in the upper quartile of the } \\
\text { market price established for a given } \\
\text { region/area, variety, trellising system, yield } \\
\text { under constraint; assumes that requested } \\
\text { activities have been carried out and takes } \\
\text { into account the quality criteria. } \\
\text { Costs: harvesting (if done by the winery) } \\
\text { and transport to the winery to be paid by the } \\
\text { grower. Responsibility of the seller for all } \\
\text { vineyard labour costs, including activities } \\
\text { requested by the buyer. } \\
\text { Mode of payment: } 30 \% \text { in May, } 70 \% \text { in } \\
\text { equal staggered payments until the end of } \\
\text { the year. Where credit has been given at } \\
\text { harvesting, the advance is deducted from the } \\
\text { first } 30 \% \text { payment. } \\
\text { Penalty (in case of breach contract): } 3 \\
\text { tonnes/ha valued at the price above, to be } \\
\text { paid by the defaulting party every remaining } \\
\text { year of the contract. } \\
\text { Enforcement institution: provincial court } \\
\text { of justice. }\end{array}$ & $\begin{array}{l}\text { Activities to be carried out in the vineyard } \\
\text { at request of the winery: } \\
\text { - Pruning. } \\
\text { - Removing root sprouts (uprooting). } \\
\text { - Leaf and cluster thinning during } \\
\text { - summertime if necessary. } \\
\text { - Application of pesticides. } \\
\text { Harvesting date and place to be fixed by the } \\
\text { winery. }\end{array}$ \\
\hline
\end{tabular}

Source: BC's written contract.

example, if $50 \%$ of the production is lost, the price will be decreased in half on the remaining production. But it remains little advantageous for the bodega, because the rest of grapes also lost in quality because of the hail. Besides, some producers could have incentives to not fertilize because they have no interest to reach higher yield. 
More interestingly, the contract also requires that producers make a commitment "to respect the decisions of the bodega as regards the works in the vineyard", that the bodega chooses the date of the grape harvest, that the per tonne price will be negotiated every year, in reference to a "market price", in the "upper quartile" for similar grapes if the producer respects the requirements of the bodega. The contract is thus left incomplete, with room for change during the growing season (this is not the case for quality incentive contracts, where the grower keeps all the residual decision and control rights) and flexible pricing.

Each grape category commands a different price range, taking into account the extra costs inherent in the development of high quality grapes, in particular the costs associated with yield limitation. Each grade also implies a different allocation of decision rights to the winery. Some contractual elements may be adjusted on a yearly basis. This is the case of some decision rights which may be allocated differently to the winery.

Pricing is another fundamental point of contract adaptation. The written contract does not include any type of price formula (target, ceilings, windows or cost-plus pricing formula) ${ }^{3}$. It only specifies that payment will be made according to the variety, region and quality in the upper quartile of the "market price", with an implicit reference to the information provided by the Bolsa de Comercio de Mendoza. However, the Board of Trade only considers the broad "premium" category for quality grapes, and does not report weekly or monthly prices for grapes, only annual figures.

To improve their bargaining position in price negotiations, growers are left to rely on hearsay about prices obtained from other bodegas, or have to use prices of winery to winery transactions published every week by the Board of Trade. As price is negotiated ex-post (after harvest) with only rough cues about market prices, one could think that the grower has little power of negotiation, and is exposed to high risk of moral hazard. However, there are very few conflicts. Indeed, both parties almost always come to an agreement, especially since the grower and the bodega have a mutual interest in maintaining stable long-term relations. Contractors do not think in terms of a one-shot

\footnotetext{
${ }^{3}$ Formal price indexation formulas are sometimes used for long term contracts in the wine industry, for example Montaigne and Sidlovits (2003) document the case of a large French wine company that offers a formal contract with stability and protection against too important price fluctuations on the input, as well as on the consumer markets.
} 
transaction, but rather of a repeated negotiation over several years. If negotiations were one-off occurrences, it would be easy for the buyer to pay an absurdly low price.

Keeping pricing flexible is crucial in Mendoza, where inflation and monetary fluctuations entail strong variations in wine prices and input costs. In grape transactions, the objective is to negotiate a "fair price", so that the losses or the profits experienced by all parties balance out over the years. One of the interviewees pointed out that fixing prices in advance (as in certain contracts in California) increases tensions between parties, and may lead to contract termination. The trading imbalances that could appear because of the market situation are compensated over the long term, with a "shared belief" of fair income distribution (Bradach and Eccles, 1989). However, while such expectations undoubtedly help to reduce disputes over rent sharing, other private devices are used to make incomplete contracts self-enforcing.

\subsection{Enforcement}

To enforce agreements, BC and their growers rely on five non legal mechanisms: (i) exit option, (ii) group assignment, (iii) reputation capital, (iv) hostages, and (v) competitive sourcing. For the middle tier wine category, only the first two mechanisms matter, whereas for high-quality wines, they are not effective, and the other three become important.

(i) Exit option: Prices are negotiated weeks and sometimes months after delivery and processing by the winery. Growers' low bargaining power is reinforced by the option to unilaterally break the contract if the negotiation is unsuccessful, a right tacitly acknowledged in Mendoza (even if generally, it is not exercised). In that case, the grapes are returned to the grower in the form of unfinished (non-aged) wine. The grower is also required to pay a fixed charge for processing. The product could then be sold on the wine market, with a good chance of fetching the market price reported for similar types of product (varietal, region, vintage). In the high-end tier, however, this option is ineffective in providing safeguards, because switching from the contractor to the spot market incurs losses. With specific sensorial characteristics, there are high search and transaction costs, no guarantee of finding a good match on the market, and a strong probability of not recovering specific investments (yield limitation) and extra costs (required practices). 
(ii) Group assignment: Price negotiations are framed by the use of grape quality groups, because there is the guarantee that growers will stay in a given group for a year, and be paid accordingly. At the high end of the spectrum, with no information on the market price for top quality grapes, this is largely ineffective.

(iii) Reputation capital: $\mathrm{BC}$ is a well established company in Argentina, with a reputation backed by its affiliation to a multinational wine and spirits company, and by relational investments with local growers such as training sessions, social events and funding of children's schooling.

(iv) Hostages: The Fondo Provincial de Transformación y Crecimiento de Mendoza, a public institution for credit and agricultural development, subsidises anti-hail nets for small-scale growers, on the condition that they have a third-party guarantor. In practice, this guarantee is generally provided by the bodega with which they have the strongest business relationship. Because of this, the company has a vested interested in the grape producer's success. By providing guarantees such as this, BC and fellow wineries construct long-lasting relationships with their contracting growers, and credibly commit to treat them fairly in business dealings.

(v) Dual sourcing: In Mendoza, wineries source on average $62 \%$ of all varietal grapes from their own vineyards (Van den Bosch and Vitale, 2010). This figure is even higher at BC for grade A and B grapes - those dedicated to ultra-premium brands. Vertical integration re-establishes termination as a credible sanction in case of growers' misbehaviour or opportunism. The complementarity between governance structures is especially helpful in enforcing incomplete contracts, and has in our opinion been overlooked in previous empirical literature on wine-grape transactions.

However, if vineyard ownership helps to make incomplete contracts self-enforcing, it is not justified by this unique factor. Other drivers, such as path-dependency, financial opportunities, and R\&D explain backward integration. 
Figure 5. Grape procurement and governance in Argentina: summary.

\begin{tabular}{|c|c|c|c|c|}
\hline Wine category & Variable & $\begin{array}{l}\text { Lower tier } \\
\text { (Basic) }\end{array}$ & $\begin{array}{l}\text { Middle tier } \\
\text { (Premium) }\end{array}$ & High-end \\
\hline Market & Wine price range* & $<$ USD 5 & USD 5-10 & $>$ USD 10 \\
\hline \multirow[t]{3}{*}{ Wine making } & $\begin{array}{l}\text { Separate } \\
\text { winemaking }\end{array}$ & No & No & Yes \\
\hline & Oak aging & No & $\begin{array}{l}0 \text { to } 6 \text { months } \\
\text { (American/ } \\
\text { French) }\end{array}$ & $\begin{array}{l}12 \text { to } 18 \text { months } \\
\text { (French) }\end{array}$ \\
\hline & Asset specificity & Low & Low & Medium to High \\
\hline \multirow{7}{*}{ Grape production } & Grading & E & $\mathrm{C}$ and $\mathrm{D}$ & $A$ and $B$ \\
\hline & Varietal & \begin{tabular}{|l}
$\begin{array}{l}\text { Criollas or } \\
\text { International } \\
\text { (blend) }\end{array}$ \\
\end{tabular} & International & International \\
\hline & Yield & $\begin{array}{l}\text { Not limited (up } \\
\text { to } 30 \text { tons/ha) }\end{array}$ & $\begin{array}{l}\text { Limited (10 to } \\
15 \text { tons/ha) }\end{array}$ & $\begin{array}{l}\text { Very limited ( } 5 \text { to } \\
9 \text { tons/ha) }\end{array}$ \\
\hline & Bud density & 15 to $25 /$ meter & 13 to $17 /$ meter & 10 to $13 /$ meter \\
\hline & Clusters density & $2 /$ bud & 2/bud & 1 to $1.5 / \mathrm{bud}$ \\
\hline & Asset specificity & Low & Low & $\begin{array}{l}\text { Medium } \\
\text { (dedicated assets) }\end{array}$ \\
\hline & Specific practices & No & $\begin{array}{l}\text { Little } \\
\text { requirements, } \\
\text { suggested } \\
\text { practices }\end{array}$ & $\begin{array}{l}\text { Greater } \\
\text { requirement (e.g. } \\
\text { leaf and cluster } \\
\text { thinning) }\end{array}$ \\
\hline \multirow[t]{2}{*}{$\begin{array}{l}\text { Grape } \\
\text { procurement }\end{array}$} & Governance & Market & $\begin{array}{l}\text { Market }+ \\
\text { Hierarchy }\end{array}$ & $\begin{array}{l}\text { Hierarchy + } \\
\text { Hybrid }\end{array}$ \\
\hline & Own vineyards** & $<10 \%$ & $50 \%$ & $>70 \%$ \\
\hline \multirow[t]{6}{*}{ Contracts } & Type & $\begin{array}{l}\text { No contract } \\
\text { (spot) }\end{array}$ & $\begin{array}{l}\text { Complete } \\
\text { contract }\end{array}$ & $\begin{array}{l}\text { Incomplete } \\
\text { contract }\end{array}$ \\
\hline & Verbal/Written & $\mathrm{n} / \mathrm{a}$ & Verbal & Verbal or written \\
\hline & Duration & No commitment & $\begin{array}{l}\text { One year, } \\
\text { rolling }\end{array}$ & One to five years \\
\hline & $\begin{array}{l}\text { Decision rights for } \\
\text { the winery }\end{array}$ & No & + & +++ \\
\hline & $\begin{array}{l}\text { Visits by winery } \\
\text { field staff }\end{array}$ & Unusual & Once a month & Frequent \\
\hline & Pricing & $\begin{array}{l}\text { Market price } \\
\text { (with public } \\
\text { regulation) }\end{array}$ & $\begin{array}{l}\text { Market price } \\
\text { and quality } \\
\text { incentives }\end{array}$ & $\begin{array}{l}\text { Negotiated } \\
\text { or fixed price/ha }\end{array}$ \\
\hline
\end{tabular}

* Price per 75 cl. bottle. Buenos Aires, retail chains, 2010.

** Our estimations based on Lumbroso (2010). 
There is indeed a long history of vertical integration by wine producers in New World chains, both downstream into logistics and distribution, and upstream into grape production (Knox, 2000; Simpson, 2011). Nowadays, a stable mix between vertical integration and contract farming is a salient feature, not only in Argentina, but also in the Chilean, New-Zealand, Australian, South-African, and Californian premium wine-grape industries (Geraci, 2004; Gwynne, 2006; Lewis et al., 2001; Ponte, 2009). According to our interviews, in the case of $\mathrm{BC}$, the need to protect brand name capital is nevertheless the most important, although not the only, motivation for developing vineyard ownership.

\section{$\underline{\text { 5. CONCLUSION }}$}

In Argentina, grape procurement for high-end wine brands is governed by a mix of corporate vineyards and agricultural contracts, allocating substantial decision rights to wineries with regards to the standards they require from their third-party growers. The comparative analysis of three wine segments within the same company confirms that contracting practices could be explained by the organisational problems faced by grape buyers. We also point out how incomplete contracts are completed ex-post in the industry, and how wineries and growers use enforcement devices to sustain their mutual understanding, while lowering transaction costs.

We are aware of the shortcomings of the study. There is a need to investigate more deeply the question of pricing in incomplete wine-grape contracts. As Ménard (2012) argues, besides the ideas of "fair price", there has been little empirical investigation into the rentsharing rules of contracts without well-defined income rights. This presents a new avenue to be explored.

There is also a need to study regulatory frameworks impacting governance structures and contract design (Oxley, 1999; Williamson, 2000). New World cases are interesting, and deserve further investigation, because contrary to European mature wine chains, grape transactions are not embedded in PDO regulation and other developed public or collective institutions (Raynaud et al., 2005; Lanotte and Traversac, 2011). Unlike Chile, where written contracts are used in the production of popular varietal wines (Martin, 2003), written contracts in Mendoza are only employed for the high-end segment. Such a 
difference may mean that the Argentinean legal system is less geared up to deal with contractual disputes relating to premium grapes. A consequence is that contractors have to invest more in reputation capital than their Chilean counterparts. This hypothesis would, of course, deserve further empirical investigation. 


\section{$\underline{\text { REFERENCES }}$}

Adelman, MA., 1949. The large firm and its suppliers. Review of Economics and Statistics, 31(2): 113-118.

Alchian, A.A. and S. Woodward, 1987. Reflections on the theory of the firm. Journal of Institutional and Theoretical Economics, 143(1): 110-136.

Allen, D.W, 1993. Pot-Bellies and Cattle Breeds as Revealing Signals. Economic Inquiry, 31(3): 481-487.

Allen, D.W, and D. Lueck, 2003. The Nature of the Farm: Contracts, Risk, and Organization in Agriculture. MIT Press, Cambridge.

Arrunada, B., L. Garicano and L. Vasquez, 2001. Contractual Allocation of Decision Rights and Incentives: The Case of Automobile Distribution. Journal of Law, Economics and Organization, 7(1): 257-286.

Arrunada, B., L. Garicano and L. Vasquez, 2005. Completing contracts ex post: how car manufacturers manage car dealers. Review of Law and Economics, 1(1): 150-173.

Ayouz, M., M. Fares and G. Martin, 2002. Choix contractuels et qualité du raisin en Argentine. Economies et Sociétés, 36(9-10): 1633-1654.

Baker, G., R. Gibbons and K. Murphy, 2002. Relational Contracts and the Theory of the Firm. Quarterly Journal of Economics, 117(1): 39-84.

Barzel, Y.A., 1982. Measurement cost and the organization of markets. Journal of Law and Economics, 25(1):27-48.

Barzel, Y.A., 2002. A Theory of the State: Economic Rights, Legal Rights, and the Scope of the State. Cambridge University Press, Cambridge.

Barzel, Y.A., 2005. Organizational Forms and Measurement Costs. Journal of Institutional and Theoretical Economics, 161(3): 357-373.

Bisson, L., 2001a. Factors influencing wine quality: what is wine quality? University Extension Bulletin. University of California, Berkeley.

Bisson, L., 2001b. In search of optimal grape maturity. Practical winery and vineyard magazine, July/August.

Bradach, J.L., 1997. Using Plural Form in the Management of Restaurant Chains. Administrative Science Quarterly, 42(2): 276-303.

Bradach, J.L. and R.G. Eccles, 1989. Price, Authority, and Trust: From Ideal Types to Plural Forms. Annual Review of Sociology, 15: 97-118.

CDFA/USDA, 2012. California Grape Crush Report. California Department of Food and Agriculture and USDA's National Agricultural Statistics Service, California Field Office, Sacramento.

David, R.J. and S.-K. Han, 2004. A systematic assessment of the empirical support for transaction cost economics. Strategic Management Journal, 25(1): 39-58.

Demsetz, H, 1998. Book review: firms, contracts and financial structure (by O. Hart). Journal of Political Economy, 106(2): 446-452.

Dutta, S., M. Bergen, J. Heide and G. John, 1995. Understanding Dual Distribution: The Case of Reps and House Account. Journal of Law, Economics and Organization, 11(1): 189-204. 
Eccles, R.G., 1981. The quasifirm in the construction industry. Journal of Economic Behavior and Organization; 2(4): 335-357.

Eggertsson, T., 1990. Economic Behavior and Institutions. Cambridge University Press, Cambridge.

Fernández-Olmos, M., J. Rosell-Martínez and M.A. Espitia-Escuer, 2009. Vertical integration in the wine industry: a transaction costs analysis on the Rioja DOC. Agribusiness, 25(2): 231-250.

Fraser, I., 2005. Microeconometric analysis of wine grape supply contracts in Australia. Australian Journal of Agricultural and Resource Economics, 49(1): 23-46.

Geraci, V.W., 2004. Fermenting a Twenty-First Century California Wine Industry. Agricultural History, 78(4): 438-465.

Goodhue, R.E., D.M. Heien, L. Hyunok and D. Sumner, 2003. Contracts and Quality in the California Winegrape Industry. Review of Industrial Organization, 23(3): 267282.

Gordon, W., 2006. Australian Wine Grape Production projections 2007-08. ABARE Research Report 06.4 Prepared for the Grape and Wine Research and Development Corporation, Canberra, June.

Greif, A., P. Milgrom and B.R. Weingast, 1994. Coordination, commitment, and enforcement: The case of the merchant guild. Journal of Political Economy, 102 (4): 745-776.

Gwynne, R.N., 2006. Governance and the wine commodity chain: Upstream and downstream strategies in New Zealand and Chilean wine firms. Asia Pacific Viewpoint, 47(3): 381-395.

Hannin, H., J.M. Codron and S. Thoyer, 2006. The International Office of Vine and Wine (OIV) and the World Trade Organization (WTO): Standardization issues in the wine sector. In: J. Bingen and L. Busch (eds.) Agricultural Standards: The Shape of the Global Food and Fiber System. Springer, Dordrecht, pp. 73-92.

He, D. and J. Nickerson, 2006. Why do firms make and buy? Efficiency, appropriability, and competition in the trucking industry. Strategic Organization, 4(1): 43-69.

Heide, J.B., 2003. Plural Governance in Industrial Purchasing. Journal of Marketing, 67(4): $18-29$

Hendrikse, G.W.J., 2003. Governance of chains and networks: A research agenda. Journal on Chain and Network Science, 3(1): 1-6.

$\mathrm{Hu}, \mathrm{Y}$ and G.W.J. Hendrikse, 2009. Allocation of Decision Rights in Fruit and Vegetable Contracts in China. International Studies of Management and Organization, 39(4): 8-30.

Hueth, B., E. Ligon, S. Wolf and S. Wu, 1999. Incentive Instruments in Fruit and Vegetables Contracts: Input Control, Monitoring, Measuring, and Price Risk. Review of Agricultural Economics, 21(2): 374-389.

Hueth, B. and T. Melkonyan, 2004. Quality Measurement and Contract Design: Lessons from the North American Sugarbeet Industry. Canadian Journal of Agricultural Economics, 52(2): 165-181.

Hviid, M., 2000. Long-Term Contracts and Relational Contracts. In: B. Bouckaert, G. De Geest (eds.) Encyclopedia of Law and Economics, pp. 46-72. 
Jang, J.-I. and M. Sykuta, 2009. Contracting for Consistency: Hog Quality and the Use of Marketing Contracts. CORI Working Paper No. 2009-02. University of Missouri, Columbia.

Kennedy, A.M., 2002. An australian case study: Introduction of quality measures and technologies in the viticultural industry. In: Proceedings of the Eleventh Australian Wine Industry Technical Conference, 7-11 October 2001, Adelaide, Australia. Winetitles, Adelaide, pp. 199-205.

Klein, B., 1996. Why Hold-Up Occurs: The Self-Enforcing Range of Contractual Relations. Economic Inquiry, 34(3): 444-463.

Klein, B., R.G. Crawford and A. Alchian, 1978. Vertical Integration, Appropriable Rents, and the Competitive Contracting Process. Journal of Law and Economics, 21(2): 297-326.

Klein, P.G, 2005. The Make-or-Buy decision: lessons from empirical studies. In: C. Ménard and M. Shirley (eds.) Handbook of New Institutional Economics. Springer, Dordrecht.

Knox, T.M., 2000. The economic organization of winemaking: French cooperatives and California corporations in historical context. PhD Dissertation. The University of Connecticut.

Lanotte, H and J.-B. Traversac, 2011. An economic history of the Champagne contracts, lessons for regional development. In: 51st Congress of the European Regional Science Association, Barcelona, 30th August-3rd September 2011.

Lazzarini, S.G., G.J. Miller and T.R. Zenger, 2004. Order with Some Law: Complementarity versus Substitution of Formal and Informal Arrangements. Journal of Law, Economics and Organization, 20(2): 261-298.

Lewis, N., W. Moran, J. Barker and P. Perrier-Cornet, 2002. Territoriality, enterprise and réglementation in industry governance. Progress in Human Geography, 26(4): 43346.

Ligon, E., 2001. Contractual Arrangements for Fresh Produce in California. ARE Update 5(2): $1-2$.

Lumbroso, S., 2010. Analyse économique des approvisionnements en raisin dans la filière vitivinicole argentine. Mimeo. Montpellier SupAgro.

Macaulay, S., 1963. Non-Contractual Relations in Business: A Preliminary Study. American Sociological Review, 28(1): 55-67.

Macher, J.T. and B.D. Richman, 2008. Transaction Cost Economics: An Assessment of Empirical Research in the Social Sciences. Business and Politics, 10(1): article 1.

Mahoney, J., 1992. The choice of organizational form: vertical financial ownership versus other methods of vertical integration. Strategic Management Journal, 13(8): 559584.

Mahoney, J. and R. McNally, 2004. Explaining and predicting the choice of organizational form: integrating performance ambiguity and asset specificity effects. Working Papers $n^{\circ} 04-0109$. University of Illinois at Urbana-Champaign, College of Business.

Martin, G., 2003. Mutation qualitative dans la viticulture Argentine: une analyse néoinstitutionnelle des contrats d'approvisionnement. PhD Dissertation, ENSAMINRA, Montpellier. 
Masten, S., 2000. Transaction-cost economics and the organization of agricultural transactions. In: M. Baye (ed.) Advances in Applied Microeconomics; Industrial Organization. Elsevier Science, New York.

Masten, S., 1984. The organization of production: evidence from the aerospace industry. Journal of Law and Economics, 27(2): 403-417.

Masten, S., and K. Crocker, 1985. Efficient Adaptation in Long-Term Contracts: Take-orPay Provisions for Natural Gas. American Economic Review, 75(5): 1083-1093.

Mazé, A., and C. Ménard, 2010. Private ordering, collective action, and the self-enforcing range of contracts. European Journal of Law and Economics, 29(1): 131-153.

Ménard, C., 2012. Hybrid Modes of Organization. Alliances, Joint Ventures, Networks, and Other 'Strange' Animals. In: R. Gibbons and J. Roberts (eds.) The Handbook of Organizational Economics. Princeton University Press, Princeton (forthcoming).

McMillan, J., and C. Woodruff, 1999. Dispute Prevention without the Courts. Journal of Law, Economics, and Organization, 15(3): 637-660.

Montaigne, E. and D. Sidlovits, 2003. Long Term Contracts and Quality in the Wine Supply Chains: Case of the Appellation "Vins des Sables du Golfe du Lion". In: 7th Annual Conference of the International Society for New Institutional Economics, Budapest, 11-13 September 2003.

Oxley, J.E., 1999. Institutional environment and the mechanisms of governance: the impact of intellectual property protection on the structure of inter-firm alliances. Journal of Economic Behavior and Organization, 38(3): 283-309.

Palay, T., 1985. The avoidance of regulatory constraints: The use of informal contracts. Journal of Law, Economics, and Organization, 1(Spring): 140-162.

Parmigiani, A., 2007. Why Do Firms Both Make and Buy? An Investigation of Concurrent Sourcing. Strategic Management Journal, 28(3): 285-311.

Ponte, S., 2009. Governing through Quality: Conventions and Supply Relations in the Value Chain for South African Wine. Sociologia Ruralis, 49(3): 236-257.

Poppo, L. and T. Zenger, 2002. Do formal contracts and relational governance function as sustitutes or complements? Strategic Management Journal, 23(8): 707-725.

Raynaud, E., L. Sauvée and E. Valceschini, 2005. Alignment between Quality Enforcement Devices and Governance Structures in the Agro-food Vertical Chains. Journal of Management and Governance, 9(1): 47-77.

Richman, B.D., 2004. Firms, Courts, and Reputation Mechanisms: Towards a Positive Theory of Private Ordering. Columbia Law Review, 104(8): 2328-2368.

Rousset, S., 2006. Stratégie de qualité et organisation de l'industrie du vin en France et dans les pays du Nouveau monde. Economies et Sociétés, 40(5): 583-598.

Simpson, J., 2011. Factor endowments, markets and vertical integration. The development of commercial wine production in Argentina, Australia and California, c1870-1914. Revista de Historia Económica (Second Series), 29(1): 39-66.

Stein, S., 2008. Our Saviors May Not Speak Spanish: Changing Markets and Strategies in Argentina's Wine Revolution, 1990-2008. AAWE Working Paper n²1. American Association of Wine Economists.

Sykuta, M., 2005. Agricultural Organization in an Era of Traceability. Journal of agricultural and applied economics, 37(2): 365-377.

Sykuta, M., and J. Parcell, 2003. Contract Structure and Design in Identity-Preserved Soybean Production. Applied Economic Perspectives and Policy, 25(2): 332-350. 
Tadelis, S., 2002. Complexity, flexibility and the make-or-buy decision. American Economic Review, 92(2): 433-437.

Traversac, J.-B., S. Rousset and P. Perrier-Cornet, 2011. Farm resources, transaction costs and forward integration in agriculture: Evidence from French wine producers. Food Policy, 36(6): 839-847.

Van den Bosch, M.-E, 2008. Zonas agroeconómicas homogéneas : San Juan y Mendoza, proyecto especifico: economía de los sistemas de producción : caracterización y prospectivas. Instituto Nacional de Tecnología Agropecuria, Mendoza.

Van den Bosch, M.-E. and J. Vitale, 2010. Caracterización de la cadena de la vid de la provincia de Mendoza, Competitividad de las cadenas agroalimentarias y agroindustriales - proyecto especifico: economía de las cadenas agroalimentarias y agroindustriales. Instituto Nacional de Tecnología Agropecuria, Mendoza.

Williamson, O.E., 1985. The Economic Institutions of Capitalism. Free Press, New York.

Williamson, O.E., 1991. Comparative economic organization: the analysis of discrete structural alternatives. Administrative Science Quarterly, 36(2): 269-296.

Williamson, O.E., 2005. The Economics of Governance. American Economic Review, 95(2): 1-18. 